\title{
Synthesis and transformation in the series of 2-((5-(2,4- and 3,4-dimethoxyphenyl)-3H-1,2,4-triazole-3-yl)thio)acetic acids
}

\author{
D. V. Dovbnia (D)*A,B,D, A. H. Kaplaushenko (DB, B, Yu. S. Frolova (DC,E
}

Zaporizhzhia State Medical University, Ukraine

A - research concept and design; B - collection and/or assembly of data; C - data analysis and interpretation; D - writing the article;

$\mathrm{E}$ - critical revision of the article; $\mathrm{F}$ - final approval of the article

The aim of the work is to develop preparative methods for the synthesis of 2-((5-(2,4- and 3,4-dimethoxyphenyl)-3H-1,2,4-triazole-3-yl) thio)acetic acids, to study the esterification reaction in this regard, to study physical and chemical properties of the obtained substances, and to predict their toxicity.

Materials and methods. Compounds were synthesized using reagents and solvents qualified as "ch.p.". The IUPAC nomenclature as supplemented was used during the preparation. The melting temperature was determined with the capillary method according to HFC (2.2.14) on the device PTP (M). Elemental analysis was determined with the ELEMENTAR vario EL cube analyzer (manufactured in Germany) (standard - sulfonamide). IR spectra were recorded using spectrophotometer Specord M-80 (manufactured in Germany) within the range of $4000-500 \mathrm{~cm}^{-1}$ (scanning was performed under the following conditions: slot program 3.0, time constant $-\mathrm{T}=3 \mathrm{~s}$, scanning time $34 \mathrm{~min}$, samples were analyzed in the form of tablets with potassium bromide). ${ }^{1} \mathrm{H}$ NMR spectra were recorded using Varian VXR-300 spectrophotometer (manufactured in the USA), dimethyl sulfoxide- $\mathrm{D}_{6}$ solvent, and tetramethylsilane was used as an internal standard. The spectra were decoded using the computer program ADVASP 1.43. Thin layer chromatography was performed using Sorbfil plates (analytical, size $10 \times 15 \mathrm{~cm}$, base: polymer substrate, sorbent: silica gel STX-1A, grain: 5-17 $\mu \mathrm{m}$, layer thickness: $110 \mathrm{~m}$ combination - silicazole).

Results. The synthesis of new 2-((5-(2,4- and 3,4-dimethoxyphenyl)-3H-1,2,4-triazole-3-yl)thio)acetic acids was carried out. These products became a basis for synthesis of a number of relevant esters. Physical and chemical properties were investigated for the synthesized compounds. The structure of the obtained substances was confirmed by elemental analysis, IR-spectroscopy, ${ }^{1} \mathrm{H}$ NMR-spectrometry, and their individuality were established by thin-layer chromatography. Computer GUSAR-online prediction of acute toxicity of 2-((5-(2,4- and 3,4-dimethoxyphenyl)-3H-1,2,4-triazole-3-yl)thio)acetic acids and their esters was performed.

Conclusions. Preparative methods for the synthesis of 2-((5-(2,4- and 3,4-dimethoxyphenyl)-3H-1,2,4-triazole-3-yl)thio)acetic acids have been developed, for which esterification reactions have been studied. Thus, physical and chemical properties of the received substances were investigated, and indicators of their toxicity were predicted.

Key words: 2-((5-(2,4- and 3,4-dimethoxyphenyl)-3H-1,2,4-triazole-3-yl)thio)acetic acids, esters, toxicity indicators.

Current issues in pharmacy and medicine: science and practice 2021; 14 (1), 12-16

Синтез і перетворення в ряду 2-((5-(2,4- та 3,4-диметоксифеніл)-3Н-1,2,4-тріазол-3-іл)тіо)ацетатних кислот

Д. В. Довбня, А. Г. Каплаушенко, Ю. С. Фролова

Мета роботи - розробити препаративні методики синтезу 2-((5-(2,4- та 3,4-диметоксифеніл)-3Н-1,2,4-тріазол-3-іл)тіо)ацетатних кислот, для яких вивчити реакцію естерифікації, дослідити фрізико-хімічні властивості речовин, що отримали, та спрогнозувати параметри їхньої токсичності.

Матеріали та методи. Синтез сполук виконали з використанням реактивів і розчинників, що мають кваліфікацію «Х.ч.». Під час підготовчої роботи використали номенклатуру IUPAC із доповненнями. Температуру плавлення визначали капілярним способом за ДФУ (2.2.14) на приладі ПТП (М). Елементний аналіз виконали на аналізаторі ELEMENTAR vario EL cube (ФPH) (стандарт сульфаніламід). ІЧ-спектри записували, використовуючи спектрофотометр Specord M-80 (ФРН) в області 4000-500 см ${ }^{-1}$ (сканування здійснювали в таких умовах: щільова програма 3.0, постійна часу - т = 3 с, час сканування -34 хв, проби аналізували у вигляді таблеток із калій бромідом). ${ }^{1} \mathrm{H}$ ЯMР-спектри реєстрували з використанням спектрофротометра Varian VXR-300 (CШA), розчинник - диметилсульфоксид-D, як внутрішній стандарт використали тетраметилсилан. Спектри розшифрували за допомогою комп'ютерної програми ADVASP 1.43. Тонкошарову хроматографрію виконали, використовуючи пластинки Sorbfil (аналітичні, розмір 10 × 15 см, основа - полімерна підкладка, сорбент - силікагель СТX-1А, зерно - 5-17 мкм, товщина шару - 110 мкм, речовина для сполучення - силіказоль).

ARTICLE

INFO

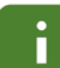

http:l/pharmed.

zsmu.edu.ualarticle/ view/226741
UDC 547.792'485.057.03/.04

DOI: $10.14739 / 2409-2932.2021 .1 .226741$

Current issues in pharmacy and medicine: science and practice 2021; 14 (1), 12-16

Key words: 2-((5-(2,4- and 3,4-dimethoxyphenyl)-3H-1,2,4-triazole-3-yl)thio)acetic acids, esters, toxicity indicators.

*E-mail: dima.dovbnya@ukr.net

Received: 28.10 .2020 // Revised: 16.11 .2020 // Accepted: 26.11.2020 
Результати. Здійснили синтез нових 2-((5-(2,4- та 3,4-диметоксифеніл)-3Н-1,2,4-тріазол-3-іл)тіо)ацетатних кислот, що стали основою отримання ряду відповідних естерів. Дослідили фізико-хімічні властивості синтезованих сполук. Будову речовин підтверджено за допомогою елементного аналізу, ІЧ-спектроскопії та ${ }^{1} \mathrm{H}$ ЯМР-спектрометрії, а їхня індивідуальність встановлена методом тонкошарової хроматографії. Виконали комп'ютерне GUSAR-online прогнозування гострої токсичності 2-((5-(2,4- та 3,4-диметоксифеніл)-3H-1,2,4-тріазол-3-іл)тіо)ацетатних кислот та їхніх естерів.

Висновки. Розробили препаративні методики синтезу 2-((5-(2,4- та 3,4-диметоксифеніл)-3Н-1,2,4-тріазол-3-іл)тіо)ацетатних кислот, для яких вивчили реакції естерифрікації. Дослідили фізико-хімічні властивості речовин, що одержали, здійснили прогнозування показників їхньої токсичності.

Ключові слова: 2-((5-(2,4- та 3,4-диметоксифеніл)-3Н-1,2,4-тріазол-3-іл)тіо)ацетатні кислоти, естери, показники токсичності.

Актуальні питання фрармацевтичної і медичної науки та практики. 2021. Т. 14, № 1(35). С. $12-16$

\section{Синтез и превращения в ряду 2-((5-(2,4- и 3,4-диметоксифенил)-3Н-1,2,4-триазол-3-ил)тио)ацетатных кислот}

\section{Д. В. Довбня, А. Г. Каплаушенко, Ю. С. Фролова}

Цель работы - разработать препаративные методики синтеза 2-((5-(2,4 и 3,4-диметоксифенил)-3Н-1,2,4-триазол-3-ил)тио) ацетатных кислот, для которых изучить реакцию эстерефикации, исследовать физико-химические свойства полученных веществ, спрогнозировать параметры их токсичности.

Материалы и методы. Синтез соединений проведен с использованием реактивов и растворителей, имеющих квалификацию «Х.ч.». При подготовке работы использовали номенклатуру IUPAC с дополнениями. Температуру плавления определяли капиллярным способом по ГФУ (2.2.14) на приборе ПТП (М). Элементный анализ проведен на анализаторе ELEMENTAR vario EL cube (ФРГ) (стандарт - сульфаниламид). ИК-спектры записывали с использованием спектрофотометра Specord M-80 (ФРГ) в области 4000-500 см-1 (сканирование осуществляли в таких условиях: щелевая программа 3.0, постоянная времени $-\tau=3 \mathrm{c}$, время сканирования - 34 мин, пробы анализировали в виде таблеток с калий бромидом). ${ }^{1} \mathrm{H}$ ЯМР-спектры регистрировали С использованием спектрофотометра Varian VXR-300 (США), растворитель - диметилсульфоксид-D, в качестве внутреннего стандарта использован тетраметилсилан. Спектры расшифровали с помощью компьютерной программы ADVASP 1.43. Тонкослойная хроматограсрия проведена с применением пластинок Sorbfil (аналитические, размер $10 \times 15$ см, основа - полимерная подложка, сорбент - силикагель СТХ-1А, зерно - 5-17 мкм, толщина слоя - 110 мкм, вещество для связывания - силиказоль).

Результаты. Проведен синтез новых 2-((5-(2,4 и 3,4-диметоксифенил)-3Н-1,2,4-триазол-3-ил)тио)ацетатных кислот, ставших основой получения ряда соответствующих эфиров. Изучили физико-химические свойства синтезированных соединений. Строение веществ подтверждено с помощью элементного анализа, ИК-спектроскопии и ${ }^{1} \mathrm{H}$ ЯMР-спектрометрии, а их индивидуальность установлена методом тонкослойной хроматографии. Проведено компьютерное GUSAR-online прогнозирование острой токсичности 2-((5-(2,4 и 3,4-диметоксифенил)-3Н-1,2,4-триазол-3-ил)тио)ацетатных кислот и их эфиров.

Выводы. Разработаны препаративные методики синтеза 2-((5-(2,4 и 3,4-диметоксифенил)-3Н-1,2,4-триазол-3-ил)тио)ацетатных кислот, для которых изучены реакции эстерификации. Исследованы физико-химические свойства полученных веществ, проведено прогнозирование показателей их токсичности.

Ключевые слова: 2-((5-(2,4 и 3,4-диметоксифенил)-3Н-1,2,4-триазол-3-ил)тио)ацетатные кислоты, сложные эфиры, показатели токсичности.

Актуальные вопросы фармацевтической и медицинской науки и практики. 2021. Т. 14, № 1(35). С. 12-16

Almost every year, unknown diseases, that require specific treatment, appear; unfortunately, existing drugs are not effective for some of them. Therefore, today the creation of affordable domestically manufactured drugs with a wide range of pharmacological activity remains an urgent task of pharmacy.

Analysis of the modern literature [1-5] indicates the prospects for the search for biologically active substances among 2-((5-(2,4- and 3,4-dimethoxyphenyl)-3H-1,2,4-triazole-3-yl) thio) acetic acids and their esters. Analysis of the work of the scientific school of ZSMU, namely the dissertation [1] and articles [2-5], demonstrates that compounds containing 2-, 3-, 4-methoxy and 3,4,5-trimethoxyphenyl substituents are highly active antimicrobial, antifungal agents and can be the basis for the creation of promising drugs [2-4]. The pharmacological activity of 2-((5-(2,4- and 3,4-dimethoxyphenyl)-3H-1,2,4-triazole-3-yl)thio)acetic acids and their esters has not been sufficiently studied. Therefore, the synthesis, study of physicochemical and biological properties of 1,2,4-triazole-3-thioacetic acids containing 2,4- and 3,4-dimethoxyphenyl substituents, as well as acid esters, from our point of view have scientific novelty and theoretical and practical significance.

\section{Aim}

The purpose of the work is to develop preparative methods for the synthesis of 2-((5-(2,4- and 3,4-dimethoxyphenyl)-3H1,2,4-triazole-3-yl)thio)acetic acids, to study the esterification reaction in this regard, to study physical and chemical properties of the obtained substances, and to predict their toxicity.

\section{Materials and methods}

In the course of practical part of the research, 2-((5-(2,4- and 3,4-dimethoxyphenyl)-3H-1,2,4-triazole-3-yl)thio)acetic acids were synthesized (compounds 2.5, 2.8, Fig. 1). This class of compounds was obtained in two ways. In the first case, the production of acids was carried out by the reaction 
between 5-(2,4- and 3,4-dimethoxyphenyl)-3H-1,2,4-triazole-3-thions (compounds 2.1, 2.2, Fig. 1) and monochloroacetic acid in the alkaline environment. As a solvent, a mixture of water and dimethylformamide in a ratio of $1: 1$ was used.

The second method was based on the interaction of ( (5(2,4- and 3,4-dimethoxyphenyl)-3H-1,2,4-triazole-3-yl)thio) acetonitrile (compounds 2.3, 2.4, Fig. 1) with hydrochloric acid; water was used as a solvent.

Esters of 2-((5-(2,4- and 3,4-dimethoxyphenyl)-3H-1,2,4triazole-3-yl)thio)acetic acids were synthesized in order to reduce the acidic properties and prolong the biological action.

It is known that esters of 2-(1,2,4-triazole-3-ylthio)acetic acids demonstrate diuretic, neuroleptic, anti-inflammatory, moderate antimicrobial and other types of biological activity [3-5]. Moreover, the strength of these compounds action is influenced by both the substituents of 1,2,4-triazole nucleus, and the structure of a complex ester group.

Acid esters have high biological activity and can also be intermediates for the synthesis of amides, hydrazides, ylidene hydrazides, and bicyclic structures - derivatives of 1,2,4-triazole.

Esters of 2-((5-(2,4- and 3,4-dimethoxyphenyl)-3H1,2,4-triazole-3-yl)thio)acetic acids (compounds 2.6, 2.7, 2.9, 2.10, Fig. 2) were obtained by a method involving the interaction of the corresponding 5-(2,4- and 3,4-dimethoxyphenyl)-3H-1,2,4-triazole-3-thione (compounds 2.1, 2.2, Fig. 2) with methyl or ethyl chloroacetic acid ester in the presence of an equimolecular amount of alkali.

In order to achieve better yields of products and their higher purity, another method was used to obtain esters of 2-((5-(2,4and 3,4-dimethoxyphenyl)-3H-1,2,4-triazole-3-yl)thio)acetic acids (compounds 2.6, 2.7, 2.9, 2.10, Fig. 2), which involves the esterification of the above mentioned acids (compounds $2.5,2.8$ ) with methyl and ethyl alcohols in the presence of a catalytic amount of concentrated sulfuric acid. After the reaction, the excess alcohol was evaporated, the residue was first thoroughly washed with sodium bicarbonate solution (to $\mathrm{pH}$ 7-8), then with water (to $\mathrm{pH} 7$ ), the precipitate was filtered off, further washed with water and dried.

Samples of esters of 2-((5-(2,4- and 3,4-dimethoxyphenyl)$3 H$-1,2,4-triazole-3-yl)thio)acetic acids (compounds 2.6, 2.7, 2.9, 2.10, Fig. 2) were obtained by two methods that did not result in melting point depression.

After recrystallization, the individuation of 2-((5-(2,4- and 3,4-dimethoxyphenyl)-3H-1,2,4-triazole-3-ylthio))acetic acids (compounds $2.5,2.8$ ) and their esters (compounds 2.6, $2.7,2.9,2.10$ ) was confirmed by a complex use of elemental analysis, IR-spectrophotometry and their individuality was confirmed chromatographically. The results of the elemental analysis were confirmed with the data on the percentage of elements $(\mathrm{C}, \mathrm{H}, \mathrm{N}, \mathrm{S})$ in the samples of the obtained compounds. There were absorption bands $-\mathrm{C}=\mathrm{N}-$ groups (in the cycle) at $1563-1603 \mathrm{~cm}^{-1}$, absorption bands of the aromatic ring at $1614-1598 \mathrm{~cm}^{-1}$ in the IR-spectra of all synthesized compounds. There were absorption bands of $\mathrm{CH}_{2}-\mathrm{COOH}$ groups at $1760 \mathrm{~cm}^{-1}$ in the IR-spectra of acids (compounds 2.5, 2.8) [6]. Moreover, the IR spectra of esters

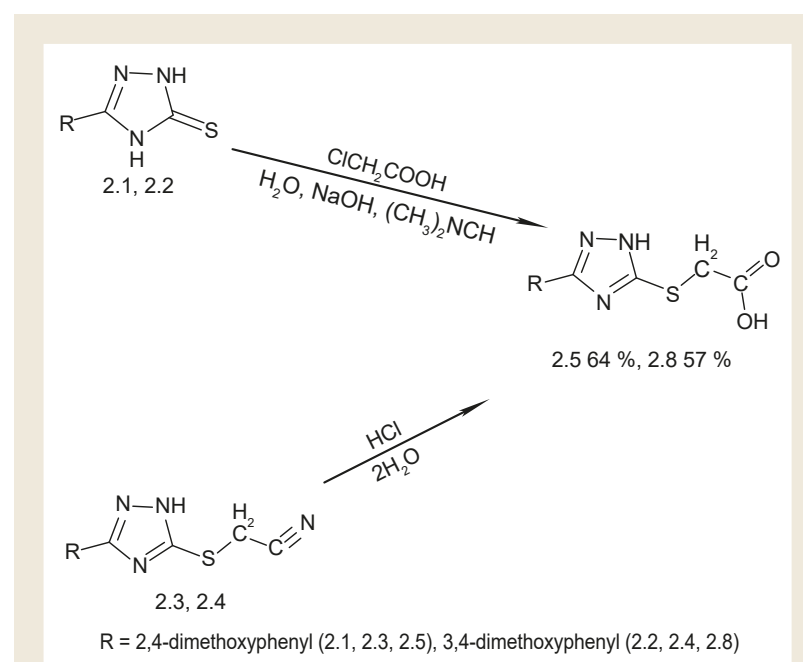

Fig. 1. Scheme of 2-((5-(2,4- and 3,4-dimethoxyphenyl)-3H-1,2,4triazole-3-yl)thio)acetic acids (compounds $2.5,2.8$ ) synthesis.

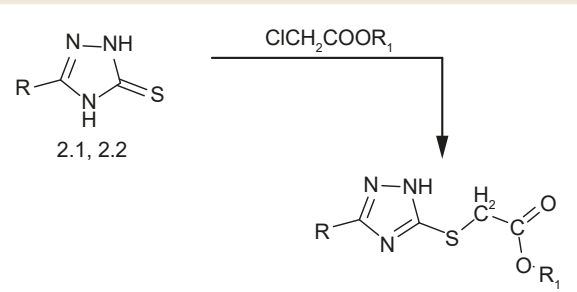

$2.677 \%, 2.767 \%, 2.973 \%, 2.1079 \%$

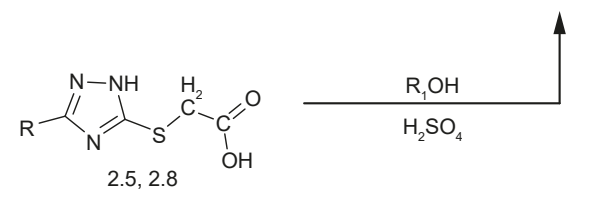

$\mathrm{R}=$ 2,4-dimethoxyphenyl $(2.1,2.5,2.6,2.7), 3$,4-dimethoxyphenyl $(2.2,2.8,2.9,2.10)$ $\mathrm{R}_{1}=\mathrm{CH}_{3}(2.6,2.7), \mathrm{C}_{2} \mathrm{H}_{5}(2.9,2.10)$

Fig. 2. Scheme of synthesis of 2-((5-(2,4- and 3,4-dimethoxyphenyl)$3 \mathrm{H}-1,2,4$-triazole-3-yl)thio)acetic acids (compounds 2.6, 2.7, 2.9, 2.10) esters.

(compounds 2.6, 2.7, 2.9, 2.10) were additionally characterized by the absorption bands of CO-C groups in the range of 1283-1227 $\mathrm{cm}^{-1}$ [6]. ${ }^{1} \mathrm{H}$ NMR-spectra of 2-((5-(2,4- and 3,4-dimethoxyphenyl)-3H-1,2,4-triazole-3-yl)thio)acetic acids (compounds 2.5, 2.8) and their esters (compounds $2.6,2.7,2.9,2.10$ ) were characterized by the presence of multiple signals of aromatic protons at $6.64-7.83 \mathrm{ppm}$, doublet signals of protons of methoxy groups at 3.65-3.90 ppm, singlet signals of the thiomethylene group have also been recorded at 3.32-3.43 ppm. In acetic acids, characteristic singlet signals of carboxyl groups were present at 12.32-12.34 ppm, and in esters of acetic acids there were signals of protons of the methyl group of the alcohol residue at $1.23-3.87 \mathrm{ppm}$.

The individuality of the synthesized compounds was proved by thin layer chromatography. The acetone : hexane : propanol $2: 1: 1$ system was used as the mobile medium. 
2-((5-(2,4- and 3,4-dimethoxyphenyl)-3H-1,2,4-triazol-3yl)thio)acetic acid (compounds $2.5,2.8$ )

Method A. In a glass of $250 \mathrm{ml} 1 \mathrm{~mole}$ of the corresponding acetonitrile $(2.3,2.4)$ nitrile and $65 \mathrm{ml}$ of hydrochloric acid were put, dissolved and left at room temperature for 5 days. Then $200 \mathrm{ml}$ of water were added, precipitated, and the whole mixture was filtered off and dried.

Method B. 1 mole of the corresponding 5-(2,4- or 3,4-dimethoxyphenyl)-3H-1,2,4-triazole-3-thione (compound 2.1), dissolved in $20 \mathrm{ml}$ of dimethylformamide, was put into a $250 \mathrm{ml}$ round bottom flask, equipped with a reflux condenser. 1 mole of $\mathrm{NaOH}$ (pre-dissolved in $20 \mathrm{ml}$ of water) and 1 mole of monochloroacetic acid were added. It was heated to the $\mathrm{pH}$ of the solution in a slightly acidic medium, after which the resulting solution was evaporated.

As a result of the reactions, the following compounds were obtained: yellow (2.5) and orange (2.8) crystalline substances insoluble in water, soluble in solutions of alkalis and alkali metal carbonates, as well as in organic solvents and solutions of mineral acids. For analysis, substances were recrystallized from a mixture of dimethylformamide-water $2: 1$.

2-((5-(2,4-dimethoxyphenyl)-3H-1,2,4-triazole-3-yl) thio)acetic acid (2.5). Yield $82 \%$, m.p. $=143-145{ }^{\circ} \mathrm{C}$. Adsorption maxima in IR-spectra $\mathrm{V}_{\mathrm{C}=\mathrm{N} \text { cycle }}=1598 \mathrm{~cm}^{-1}$; $\mathrm{V}_{\mathrm{CH} 3}^{\mathrm{s} / \mathrm{as}}=1388 / 1436 \mathrm{~cm}^{-1} ; \mathrm{V}_{\mathrm{Ar}}=1609 \mathrm{~cm}^{-1} ; \mathrm{V}_{\mathrm{C}-\mathrm{S}}=701 \mathrm{~cm}^{-1}$. ${ }^{1} \mathrm{H}$ NMR (400 MHz, DMSO-d6) d 3.32 (2H, s, S-CH $)$; 3.84-3.90 (6H, d, O-CH $)$; $4.2(1 \mathrm{H}, \mathrm{s}, \mathrm{CH}) ; 6.67-7.83(3 \mathrm{H}$, m, $\left.\mathrm{C}_{6} \mathrm{H}_{3}\right) ; 12.34(1 \mathrm{H}, \mathrm{s}, \mathrm{COOH})$. Calcd for $\mathrm{C}_{12} \mathrm{H}_{13} \mathrm{~N}_{3} \mathrm{O}_{4} \mathrm{~S} \%$ : C, 48.81; H, 4.44; N, 14.23; S, 10.86. Found \%: C, 48.82; $\mathrm{H}, 4.45 ; \mathrm{N}, 14.21 ; \mathrm{S}, 10.86$.

2-((5-(3,4-dimethoxyphenyl)-3H-1,2,4-triazole-3-yl) thio)acetic acid (2.8). Yield $83 \%$, m.p. $=82-84{ }^{\circ} \mathrm{C}$. Adsorption maxima in IR-spectra $\mathrm{V}_{\mathrm{C}=\mathrm{N} \text { cycle }}=1602 \mathrm{~cm}^{-1}$; $\mathrm{V}_{\mathrm{CH} 3}^{\mathrm{s} / \mathrm{s}}=1370 / 1438 \mathrm{~cm}^{-1} ; \mathrm{V}_{\mathrm{Ar}}=1601 \mathrm{~cm}^{-1} ; \mathrm{V}_{\mathrm{C}-\mathrm{S}}=694 \mathrm{~cm}^{-1}$. ${ }^{1} \mathrm{H}$ NMR (400 MHz, DMSO-d6) d 3.38 (2H, s, S-CH $)$; $3.65-3.83\left(6 \mathrm{H}, \mathrm{d}, \mathrm{O}-\mathrm{CH}_{3}\right) ; 4.22(1 \mathrm{H}, \mathrm{s}, \mathrm{CH}) ; 6.98-7.49(3 \mathrm{H}$, m, $\left.\mathrm{C}_{6} \mathrm{H}_{3}\right) ; 12.32(1 \mathrm{H}, \mathrm{s}, \mathrm{COOH})$. Calcd for $\mathrm{C}_{12} \mathrm{H}_{13} \mathrm{~N}_{3} \mathrm{O}_{4} \mathrm{~S} \%$ : C, 48.81; H, 4.44; N, 14.23; S, 10.86. Found \%: C, 48.82; $\mathrm{H}, 4.45 ; \mathrm{N}, 14.21 ; \mathrm{S}, 10.86$.

Esters of 2-((5-(2,4- and 3,4-dimethoxyphenyl)-3H-1,2,4triazole-3-yl)thio)acetic acids (compounds 2.6, 2.7, 2.9, 2.10).

Method A. To a solution of 0.01 mole of sodium hydroxide in $5 \mathrm{ml}$ of water, 0.01 mole of the corresponding 5-R-1,2,4triazole-3-thione $(2.1,2.2)$ in $50 \mathrm{ml}$ of ethanol and 0.01 mole of monochloroacetic acid methyl ester were added. The mixture was boiled for 5 hours, the solvent was evaporated, the residue was washed with distilled water, and crystallized from a mixture of ethanol-water 3:1.

Method B. A mixture of 0.01 mole of the corresponding 2-((5-(2,4- or 3,4-dimethoxyphenyl)-3H-1,2,4-triazole-3-yl) thio)acetic acid (compound 2.5, 2.8), $30 \mathrm{ml}$ of alcohol (methanol, ethanol) and $0.5 \mathrm{ml}$ of concentrated sulfuric acid was boiled for 10 hours, the solvent was evaporated, the residue was neutralized with sodium bicarbonate solution, which resulted in obtaining compounds 2.6, 2.7, 2.9, 2.10. White crystalline substances were insoluble in solutions of alkalis and alkali metal carbonates, sparingly soluble in water, and soluble in organic solvents. For analysis, it was purified by recrystallization from ethanol-water $3: 1$.

Methyl 2-((5-(2,4-dimethoxyphenyl)-3H-1,2,4-triazole3-yl)thio)acetate (2.6). Yield $77 \%$, m.p. $=118-120{ }^{\circ} \mathrm{C}$. Adsorption maxima in IR-spectra $\mathrm{V}_{\mathrm{C}=\mathrm{N} \text { cycle }}=1603 \mathrm{~cm}^{-1}$; $\mathrm{V}_{\mathrm{CH} 3}^{\mathrm{s} / \mathrm{ss}}=1367 / 1444 \mathrm{~cm}^{-1} ; \mathrm{V}_{\mathrm{Ar}}=1598 \mathrm{~cm}^{-1} ; \mathrm{V}_{\mathrm{CO}}=1663 \mathrm{~cm}^{-1}$; $\mathrm{V}_{\mathrm{C}-\mathrm{O}-\mathrm{C}}=1283 \mathrm{~cm}^{-1} ; \mathrm{V}_{\mathrm{C}-\mathrm{S}}=693 \mathrm{~cm}^{-1} .{ }^{1} \mathrm{H} \mathrm{NMR}(400 \mathrm{MHz}$, DMSO-d6) d 3.40 (2H, s, S-CH $)$; $3.87\left(3 \mathrm{H}, \mathrm{s}, \mathrm{CH}_{3}\right)$; 3.86$3.89\left(6 \mathrm{H}, \mathrm{d}, \mathrm{O}-\mathrm{CH}_{3}\right) ; 4.18(1 \mathrm{H}, \mathrm{s}, \mathrm{CH}) ; 6.67-7.81(3 \mathrm{H}, \mathrm{m}$, $\mathrm{C}_{6} \mathrm{H}_{3}$ ). Calcd for $\mathrm{C}_{13} \mathrm{H}_{15} \mathrm{~N}_{3} \mathrm{O}_{4} \mathrm{~S} \%$ : C, 50.48; H, 4.89; N, 13.58; S, 10.36. Found \%: C, 50.50; H, 4.90; N, 13.56; S, 10.35 .

Ethyl 2-((5-(2,4-dimethoxyphenyl)-3H-1,2,4-triazole3-yl)thio)acetate (2.7). Yield $67 \%$, m.p. $=129-131{ }^{\circ} \mathrm{C}$. Adsorption maxima in IR-spectra $\mathrm{V}_{\mathrm{C}=\mathrm{N} \text { cycle }}=1598 \mathrm{~cm}^{-1}$; $\mathrm{V}_{\mathrm{CH} 3}^{\mathrm{s} / \mathrm{as}}=1383 / 1438 \mathrm{~cm}^{-1} ; \mathrm{V}_{\mathrm{Ar}}=1603 \mathrm{~cm}^{-1} ; \mathrm{V}_{\mathrm{CO}}=1723$ $\mathrm{cm}^{-1} ; \mathrm{V}_{\mathrm{C}-\mathrm{O}-\mathrm{C}}=1227 \mathrm{~cm}^{-1} ; \mathrm{V}_{\mathrm{C}-\mathrm{S}}=700 \mathrm{~cm}^{-1} .{ }^{1} \mathrm{H}$ NMR $(400$ MHz, DMSO-d6) d $1.25\left(3 \mathrm{H}, \mathrm{s}, \mathrm{CH}_{3}\right) ; 3.43\left(2 \mathrm{H}, \mathrm{s}, \mathrm{S}-\mathrm{CH}_{2}\right)$; 3.80-3.86 (6H, d, O-CH $)$; $4.23(1 \mathrm{H}, \mathrm{s}, \mathrm{CH}) ; 6.64-7.77(3 \mathrm{H}$, m, $\mathrm{C}_{6} \mathrm{H}_{3}$ ). Calcd for $\mathrm{C}_{14} \mathrm{H}_{17} \mathrm{~N}_{3} \mathrm{O}_{4} \mathrm{~S} \%: \mathrm{C}, 52.00 ; \mathrm{H}, 5.30 ; \mathrm{N}$, 12.99; S, 9.91. Found \%: C, 51.99; H, 5.28; N, 13.00; S, 9.90.

Methyl 2-((5-(3,4-dimethoxyphenyl)-3H-1,2,4-triazole$3-y$ l)thio)acetate (2.9). Yield $73 \%$, m.p. $=120-122{ }^{\circ} \mathrm{C}$. Adsorption maxima in IR-spectra $\mathrm{V}_{\mathrm{C}=\mathrm{N} \text { cycle }}=1563 \mathrm{~cm}^{-1}$; $\mathrm{V}_{\mathrm{CH} 3}^{\mathrm{s} / \mathrm{as}}=1377 / 1470 \mathrm{~cm}^{-1} ; \mathrm{V}_{\mathrm{Ar}}=1600 \mathrm{~cm}^{-1} ; \mathrm{V}_{\mathrm{CO}}=1695 \mathrm{~cm}^{-1}$; $\mathrm{V}_{\mathrm{C}-\mathrm{O}-\mathrm{C}}=1230 \mathrm{~cm}^{-1} ; \mathrm{V}_{\mathrm{C}-\mathrm{S}}=704 \mathrm{~cm}^{-1} .{ }^{1} \mathrm{H} \mathrm{NMR}(400 \mathrm{MHz}$, DMSO-d6) d 3.37 (2H, s, S-CH $)$; $3.84\left(3 \mathrm{H}, \mathrm{s}, \mathrm{CH}_{3}\right)$; 3.69$3.89\left(6 \mathrm{H}, \mathrm{d}, \mathrm{O}-\mathrm{CH}_{3}\right) ; 4.17(1 \mathrm{H}, \mathrm{s}, \mathrm{CH}) ; 6.97-7.50(3 \mathrm{H}, \mathrm{m}$, $\mathrm{C}_{6} \mathrm{H}_{3}$ ). Calcd for $\mathrm{C}_{13} \mathrm{H}_{15} \mathrm{~N}_{3} \mathrm{O}_{4} \mathrm{~S} \%$ : C, 50.48; H, 4.89; N, 13.58; S, 10.36. Found \%: C, 50.50; H, 4.90; N, 13.56; S, 10.35 .

Ethyl 2-((5-(3,4-dimethoxyphenyl)-3H-1,2,4-triazole3-yl)thio)acetate (2.10). Yield $79 \%$, m.p. $=115-117{ }^{\circ} \mathrm{C}$. Adsorption maxima in IR-spectra $\mathrm{V}_{\mathrm{C}=\mathrm{N} \text { cycle }}=1598 \mathrm{~cm}^{-1}$; $\mathrm{V}_{\mathrm{CH} 3}^{\mathrm{s} / \mathrm{as}}=1388 / 1433 \mathrm{~cm}^{-1} ; \mathrm{V}_{\mathrm{Ar}}=1605 \mathrm{~cm}^{-1} ; \mathrm{V}_{\mathrm{C}-\mathrm{S}}=695 \mathrm{~cm}^{-1}$. ${ }^{1} \mathrm{H}$ NMR (400 MHz, DMSO-d6) d $1.23\left(3 \mathrm{H}, \mathrm{s}, \mathrm{CH}_{3}\right) ; 3.41$ $\left(2 \mathrm{H}, \mathrm{s}, \mathrm{S}-\mathrm{CH}_{2}\right) ; 3.70-3.86\left(6 \mathrm{H}, \mathrm{d}, \mathrm{O}-\mathrm{CH}_{3}\right) ; 4.21(1 \mathrm{H}, \mathrm{s}, \mathrm{CH})$; 6.95-7.49 (3H, m, $\left.\mathrm{C}_{6} \mathrm{H}_{3}\right)$. Calcd for $\mathrm{C}_{14} \mathrm{H}_{17} \mathrm{~N}_{3} \mathrm{O}_{4} \mathrm{~S} \%$ : C, 52.00; H, 5.30; N, 12.99; S, 9.91. Found \%: C, 51.99; H, 5.28; N, 13.00; S, 9.93 .

In order to exclude potentially toxic substances as unpromising objects of experimental pharmacological screening at the stage preceding the synthetic part, the prediction of acute toxicity of 2-((5-(2,4- and 3,4-dimethoxyphenyl))-3H-1,2,4triazole-3-yl)thio)acetic acids (compounds 2.5,2.8) and their esters (compounds 2.6, 2.7, 2.9, 2.10) was performed using the GUSAR-online program. Computer prediction of acute toxicity of synthesized compounds was performed according to the structural formulas of the compounds in the online version of the program GUSAR-online [7].

\section{Results}

As predicted by GUSAR-online for tested 2-((5-(2,4- and 3,4-dimethoxyphenyl)-3H-1,2,4-triazole-3-yl)thio)acetic acids (compounds 2.5, 2.8) and their esters (compounds 2.6, $2.7,2.9,2.10$ ), the average lethal dose of $\mathrm{LD}_{50}$ for the corresponding acetic acids was when administered: intraperitoneally - from 455.4 to $480.1 \mathrm{mg} / \mathrm{kg}$, intravenously - from 
315.1 to $340.5 \mathrm{mg} / \mathrm{kg}$, orally - from 578.8 to $1235.0 \mathrm{mg} / \mathrm{kg}$ and subcutaneously - from 1043.0 to $1150.0 \mathrm{mg} / \mathrm{kg}$. The average lethal dose of $\mathrm{LD}_{50}$ for the corresponding esters of acetic acid was when administered: intraperitoneally - from 801.9 to $866.1 \mathrm{mg} / \mathrm{kg}$, intravenously - from 246.6 to 351.0 $\mathrm{mg} / \mathrm{kg}$, orally - from 955.3 to $1457.0 \mathrm{mg} / \mathrm{kg}$ and subcutaneously - from 1121.0 to $2015.0 \mathrm{mg} / \mathrm{kg}$.

According to the results of the prediction of the toxicity index, it should be noted that all compounds belong to low-toxic and practically non-toxic substances, which corresponds to the $4^{\text {th }}$ and $5^{\text {th }}$ toxicity class according to the classification of K. K. Sidorov and according to the OECD classification [8].

\section{Discussion}

New 2-((5-(2,4- and 3,4-dimethoxyphenyl)-3H-1,2,4-triazole-3-yl)thio)acetic acids were synthesized, becoming the basis for the production of a number of suitable esters. The structure of the obtained substances was confirmed by elemental analysis, the obtained results confirm the data on the percentage of elements $(\mathrm{C}, \mathrm{H}, \mathrm{N}, \mathrm{S})$ in the samples of the obtained compounds, IR-spectroscopy, in the IR-spectra of acids (compounds 2.5, 2.8) $\mathrm{CH}_{2}$ absorption bands - $\mathrm{COOH}$ groups at $1760 \mathrm{~cm}^{-1}$ [6]. Besides, the IR spectra of esters (compounds 2.6, 2.7, 2.9, 2.10) were additionally characterized by absorption bands of CO-C groups in the range of 1283-1227 $\mathrm{cm}^{-1}[6]$ and ${ }^{1} \mathrm{H}$ NMR-spectrometry. In acetic acids, characteristic singlet signals of carboxyl groups were present at $12.32-12.34 \mathrm{ppm}$, and in esters of acetic acids there were signals of protons of the methyl group of the alcohol residue at $1.23-3.87 \mathrm{ppm}$, and their individuality was established by thin layer chromatography. According to the results of computer GUSAR-online prediction of toxicity indicators, it should be noted that all compounds were low-toxic and virtually non-toxic substances, which corresponds to 4 and 5 toxicity class according to the classification of K. K. Sidorov and the OECD classification [8].

\section{Conclusions}

1. Preparative methods have been developed and the synthesis of 2-((5-(2,4- and 3,4-dimethoxyphenyl)-3H-1,2,4triazole-3-yl)thio)acetic acids and their esters has been carried out.

2. The structure of the obtained compounds was confirmed by elemental analysis of IR-spectroscopy, ${ }^{1} \mathrm{H}$ NMR-spectra, and their individuality was justified by thin layer chromatography.

3. Computerized prediction of acute toxicity was performed for the synthesized compounds, which showed the possibility of searching for potential drugs based on them.

\section{Funding}

The research is carried out within the research topic of Zaporizhzhia State Medical University: "Investigation of synthetic, physical-chemical and biological properties of 5-aryl- and 5-heteryl-1,2,4-triazole-3-thione derivatives", State registration number 0113 U005084.
Conflicts of interest: authors have no conflict of interest to declare. Конфлікт інтересів: відсутній.

Information about authors:

Dovbnia D. V., Senior Laboratory Assistant of the Department of Physical and Colloidal Chemistry, Zaporizhzhia State Medical University, Ukraine. ORCID ID: 0000-0001-6170-144X

Kaplaushenko A. H., Dr.hab., Professor, Head of the Department of

Physical and Colloidal Chemistry, Zaporizhzhia State Medical University, Ukraine.

ORCID ID: 0000-0003-3704-5539

Frolova Yu. S., PhD, Assistant of the Department of Physical and Colloidal Chemistry, Zaporizhzhia State Medical University, Ukraine. ORCID ID: 0000-0002-3995-5088

\section{Відомості про авторів:}

Довбня Д. В., старший лаборант, каф. фрізколоїдної хімії, Запорізький державний медичний університет, Україна.

Каплаушенко А. Г., д-р фарм. наук, професор, зав. каф. фізколоїдної хімії, Запорізький державний медичний університет, Україна.

Фролова Ю. С., PhD, асистент, каф. фрізколоїдної хімії, Запорізький державний медичний університет, Україна.

\section{Сведения об авторах:}

Довбня Д. В., старший лаборант каф. физколлоидной химии, Запорожский государственный медицинский университет, Украина.

Каплаушенко А. Г., д-р фарм. наук, профессор, зав. каф. физколлоидной химии, Запорожский государственный медицинский университет, Украина.

Фролова Ю. С., PhD, ассистент, каф. физколлоидной химии,

Запорожский государственный медицинский университет, Украина.

\section{References}

[1] Syntez ta doslidzhennia biolohichno aktyvnykh pokhidnykh 1,2,4-triazol-3-tionu, shcho mistiat metoksyfenilni zamisnyky. Dys. kand. farm. nauk: 15.00.02. [Synthesis and study of biologically active derivatives of 1,2,4-triazole-3-thione containing methoxyphenyl substituents] (Dissertation PhD). Zaporizhzhia State Medical University. [in Ukrainian].

[2] Kaplaushenko, A. H., Knysh, E. H., Panasenko, O. I, Sameliuk, Yu. H., Kucheriavyi, Yu. M., Shcherbak, M. O., Kaplaushenko, T. M., Rud, A. M., \& Hulina, Yu. S. (2016). Praktychne znachennia ta zastosuvannia pokhidnykh 1,2,4-triazolu [Practical significance and application of 1,2,4-triazole derivatives]. Zaporizhzhia: ZSMU. [in Ukrainian].

[3] Kaplaushenko, A. G. (2009). Metody syntezu ta biolohichna aktyvnist 1,2,4-tryazol-3-tioniv [Synthesis methods and biological activity of 1,2,4-triazol-3-thions]. Ukrainskyi biofarmatsevtychnyi zhurnal, (4), 48-53. [in Ukrainian].

[4] Kaplaushenko, A. G. (2015). Khimichni vlastyvosti amino- i tiozamishchenykh 1,2,4-triazoliv [Chemical properties of amino and thio-substituted 1,2,4-triazoles]. Current issues in pharmacy and medicine: science and practice, (1). 101-106. [in Ukrainian]. https:// doi.org/10.14739/2409-2932.2015.1.41702

[5] Kaplaushenko, A. G. (2013). Vykorystannia pokhidnykh 1,2,4-triazolu yak takykh, shcho shyroko zastosovuiut u medytsyni, ta stvorennia potentsiinykh likarskykh zasobiv na osnovi danoho heterotsyklu [The use of 1,2,4-triazole derivatives as those, that are widely used in medicine, and the creation of potential medicines based on this heterocycle]. Scientific journal of the Ministry of Health of Ukraine, (3), 152-159. [in Ukrainian].

[6] Kazitsyna L. A., \& Kupletskaya N. B. (1979). Primenenie UF-, IK-, YaMR- i mass-spektroskopii $v$ organicheskoi khimii [Application of UV, IR, NMR and mass spectroscopy in organic chemistry]. Moscow: Moscow State University. [in Russian].

[7] GUSAR-online. (n.d.). Way2Drug.com. http://www.way2drug.com/ gusar/acutoxpredict.html

[8] Sidorov, K. K. (1973). O klassifikatsii toksichnosti yadov pri parenteral'nykh sposobakh vvedeniya [About the poison toxicity classification in parenteral administration methods]. Toksikologiya novykh promyshlennykh veshchestv, 13, 45-71. [in Russian]. 